Check for updates

Cite this: RSC Adv., 2018, 8, 2653

Received 3rd December 2017

Accepted 5th January 2018

DOI: $10.1039 / c 7 r a 13007 d$

rsc.li/rsc-advances

\title{
Amino acid composition and nutritional value evaluation of Chinese chestnut (Castanea mollissima Blume) and its protein subunit
}

\author{
Fang Yang,,$^{\mathrm{a}}$ Xingjian Huang, $\dot{\dagger}^{\mathrm{b}}$ Conglan Zhang, ${ }^{\mathrm{c}}$ Mei Zhang, ${ }^{\mathrm{a}}$ Chao Huang ${ }^{\mathrm{a}}$ \\ and Hao Yang (iD *a
}

\begin{abstract}
The amino acid composition, nutritional value and proteins subunit of chestnuts (Castanea mollissima Blume) from three regions of China (Henan, Hunan, and Guangdong) were investigated. Experimental results showed that the albumin fraction dominated the chestnut protein composition, but globulin and prolamin were nondetectable. All the Chinese chestnut proteins had a nutritionally balanced amino acid composition. Their amino acid score (AAS) could reach the FAO/WHO (2013) requirement for essential amino acids for older children, adolescents and adults. Leucine was the first limiting amino acid for all the Chinese chestnut protein isolates and digestible indispensable amino acid scores (DIAAS) were more than 90 (Leu). The sodium dodecyl sulphate polyacrylamide gel electrophoresis (SDS-PAGE) spectra showed that different Chinese chestnut protein isolates had almost the same band components, which were mainly comprised of seven polypeptide segments with the molecular weights of (91-93) kDa, (7072) $\mathrm{kDa},(53-55) \mathrm{kDa}, 37 \mathrm{kDa},(27-33) \mathrm{kDa}, 20 \mathrm{kDa}$ and (5-15) kDa. The amino acid compositions and the abundance of low molecular weight proteins indicated that Chinese chestnut could be utilized as a good source of plant protein for human nutrition.
\end{abstract}

\section{Introduction}

Chestnut is an important edible fruit, which has a long growing history over 2000 years in China. It contains considerable essential fatty acids, fibers, saccharides, vitamins, and minerals. ${ }^{\mathbf{1}, 2}$ In addition, chestnut is also an excellent source of plant protein. The average crude protein of $100 \mathrm{~g}$ fresh chestnut fruit was estimated to be $3.5 \mathrm{~g}$, which represented approximately $9.2 \%$ of the recommended daily intake (RDI) for females and $7.6 \%$ of the RDI for males. ${ }^{3}$ It is well known that plant protein is an alternative to animal protein for human nutrition, which contributes about $65 \%$ of the per capita supply of protein within the scope of the global. Furthermore, plant protein can be used as a complete and well-balanced source of amino acids to meet the physiological needs of the human body. ${ }^{4,5}$ A recent study showed that the predominant free amino acids in chestnut were aspartic acid, asparagine and glutamic acid.,

${ }^{a}$ Key Laboratory for Green Chemical Process of Ministry of Education, Wuhan Institute of Technology, Wuhan, 430205, China. E-mail: hyang@wit.edu.cn; Tel: $+86-13377876683$

${ }^{b}$ Key Laboratory of Environment Correlative Dietology, Ministry of Education, Huazhong Agricultural University, Wuhan, 430070, China

${ }^{c}$ Department of Biological Engineering, Hubei University Zhixing College, Wuhan, 430011, China

$\dagger$ Co-first author contributed equally to this work.
Therefore, chestnut has a great potential to be used as a nutritional food.

In addition to amino acids, protein subunits have caused extensive attention because amino acids from single peptides or peptide containing protein hydrolysates are easier to be absorbed than those from equivalent mixtures of free amino acids. ${ }^{8,9}$ Besides, protein subunits have relationship to their specific bioactivity. ${ }^{10-12}$ For example, Wang and $\mathrm{Ng}$ isolated a novel antifungal protein from Chinese chestnut seeds and the active protein exhibited a molecular mass of $37 \mathrm{kDa} \cdot{ }^{13}$ Collada et al. purified a $20 \mathrm{kDa}$ protein from cotyledons of recalcitrant chestnut seeds. The isolated protein could increase the renaturation yields of chemically denatured citrate synthase and prevent the irreversible thermal inactivation. ${ }^{14}$

Chestnut is geographically distributed in three major areas: Europe with Castanea sativa Miller, Asia with Castanea crenata Sieb. et Zucc. (Japan) and Castanea mollissima Blume (China and Korea), and North America with Castanea dentata (Marsh.) Borkh. As far as we know, the nutritional value evaluation and the protein subunit of fresh Chinese chestnut (Castanea mollissima Blume) has not been reported yet. In this study, the nutritional properties of chestnut (Castanea mollissima Blume) from three different regions of China were evaluated, which included amino acid composition, amino acid score (AAS), the predicted protein efficiency ratio (PER), essential amino acid index (EAAI), and digestible indispensable amino acid score (DIAAS). ${ }^{15}$ Their difference in subunit components was also 
investigated by sodium dodecyl sulphate polyacrylamide gel electrophoresis (SDS-PAGE). The purpose of this study is to provide a fundamental information of amino acid composition and nutritional value of Chinese chestnut. In addition, it also provides a reference for future study on the relationship between protein subunit structure and functionality of chestnut protein.

\section{Materials and methods}

\section{Materials}

Chestnuts (Castanea mollissima Blume) from three different regions of China from North to South (Henan, Hubei, and Guangdong) with a $23^{\circ}$ to $34^{\circ}$ latitude span, harvested in the fall of 2014, were used in this study. They were purchased fresh either from chestnut processors or from the distributors, and they were kept in a cooler for no more than 2 weeks if long distance shipment was required. The acquisition was done through local contacts (collaborators or colleagues) to ensure that only regionally grown chestnuts were collected. Hence, chestnut samples were named as their geographic growing locations from north to south in China: HEN (Henan province), HUN (Hunan province), and GD (Guangdong province). The three different regions (Henan, Hunan and Guangdong) were at the same longitude (113 degree), and the average temperatures in the fall season (August-October) were $20.6{ }^{\circ} \mathrm{C}, 23.8{ }^{\circ} \mathrm{C}$, and $26.2^{\circ} \mathrm{C}$, respectively. Their average precipitations were $641 \mathrm{~mm}$, $1400 \mathrm{~mm}$, and $1777 \mathrm{~mm}$, respectively.

Fresh chestnuts (1000 g) per region were previously cross-cut on the top according to a previous work, ${ }^{\mathbf{1 6}}$ then they were peeled with a knife and the nuts were rapidly cut into small. Three independent tests (replications) were performed. In each replication, 20-30 shelled nuts were diced into small pieces, and approximately $200 \mathrm{~g}$ of the mixture was milled in a Model FW80 high-speed grinder (Teste Instrument Co., Ltd., Tianjin, China) to obtain fine particles. They were placed in sealed plastic bags, kept at $2{ }^{\circ} \mathrm{C}$ and analyzed within seven days.

Chemicals and reagents were of analytical grade and obtained from Sinopharm (Shanghai, China) and Sigma Chemical (St. Louis, MO, USA). Water used in the experiments was ultrapure deionized water.

\section{Proximate chemical analysis}

The moisture content of chestnuts was analyzed by gravimetric method using a drying oven (DHG-9075A, Yiheng, Shanghai, China) at $101 \pm 2{ }^{\circ} \mathrm{C}$ until a constant weight was obtained. The ash content and total protein nitrogen were analyzed using AOAC methods (AOAC, 2000). Sample digestion was carried out in a digestion system sealed with a cork, and copper was used as a catalyst. The percentage of nitrogen was converted to crude protein by multiplying with 5.30 , which was specific for chestnut fruit. $^{17}$

\section{Protein fractionation}

Different chestnut protein fractions were isolated by sequentially extracting defatted chestnut powder with different solvents according to the method described by Chavan et al. ${ }^{18}$ Briefly, defatted and dried chestnut powder was fully dissolved in distilled water and extracted over $45 \mathrm{~min}$ at room temperature, then the suspension was centrifuged at $4200 \mathrm{rpm}$ for $20 \mathrm{~min}$. The residues were re-extracted twice with the same solvent. The recovered filtrates were combined and designated the "watersoluble fraction (albumin)". The residue from aqueous solution extraction was further fully dissolved with $0.5 \mathrm{M} \mathrm{NaCl}$ solution ( $\mathrm{pH}$ 7.0) in order to obtain globulin. The residue from above salt solution extraction was further fully dissolved with $70 \%(\mathrm{v} / \mathrm{v})$ ethanol solution at $65{ }^{\circ} \mathrm{C}$ in a shaking water bath in order to obtain prolamin. The residue from above ethanol solution extraction was further fully dissolved with $0.1 \mathrm{M}$ sodium hydroxide in order to obtain glutelin. Filtrates containing the desired protein fractions were dialyzed against distilled water for $48 \mathrm{~h}$ at $4{ }^{\circ} \mathrm{C}$ and separately lyophilized. Protein content in each fraction was determined according to AOAC 2000. All lyophilized chestnut protein fractions were then stored in the refrigerator (4 ${ }^{\circ} \mathrm{C}$ ) in airtight plastic bottles until further use.

\section{Amino acid composition and evaluation of nutritional parameters}

Two milligrams of defatted chestnut power samples were hydrolyzed with $0.5 \mathrm{~mL} 6 \mathrm{M} \mathrm{HCl}$ in a sealed ampoule containing $8 \mathrm{~mL}$ phenol (for protection of tyrosine) and $0.25 \mu \mathrm{L}$ norleucine (catalogue no. N8513, Sigma, as an internal standard) for $24 \mathrm{~h}$ at $110^{\circ} \mathrm{C}$ under vacuum. The acid hydrolysate was dried completely using a Speedvac concentrator (Savant Instrument, Farmingdale, $\mathrm{NY}$ ) and the dry residue was re-dissolved in $0.5 \mathrm{~mL}$ of citrate buffer (Beckman A303084, CA). The sample was filtered through a $0.45 \mu \mathrm{m}$ nylon filter before being analyzed with an automated Amino Acid Analyzer (Hitachi 835-50, Japan). Sulphurcontaining amino acids, cystine and methionine were determined after a pre-hydrolysis oxidation with performic acids. ${ }^{\mathbf{1 9}}$ Cystine was analyzed according to Okuno's report. ${ }^{20}$ The contents of different amino acids recovered were presented as $\mathrm{g} /$ $100 \mathrm{~g}$ protein and were compared with the FAO/WHO (2013) reference pattern. The ratio of essential to total amino acids was reported as $E / T(\%)$. The essential amino acid (EAA) score was calculated by the method of FAO/WHO as shown below: ${ }^{21}$

$$
\mathrm{EAA}=\frac{\mathrm{mg} \text { of EAA in } 1 \mathrm{~g} \text { of test protein }}{\mathrm{mg} \text { of EAA in } 1 \mathrm{~g} \text { of egg protein }} \times 100
$$

Essential amino acid index (EAAI) was calculated by the method of FAO/WHO as shown below:

$$
\mathrm{EAAI}=\sqrt[n]{\prod_{i=1}^{n} \mathrm{EAA} i}
$$

The predicted protein efficiency ratio (PER) values were calculated from their amino acid composition based on three equations developed by Chavan et al., ${ }^{22}$ as given below:

$$
\begin{aligned}
& \text { PER-1 }=-0.684+0.456(\text { Leu })-0.047(\text { Pro }) \\
& \text { PER-2 }=-0.468+0.454(\text { Leu })-0.105(\text { Tyr })
\end{aligned}
$$




$$
\begin{aligned}
\text { PER-3 }= & -1.816+0.435(\text { Met })+0.780(\text { Leu }) \\
& +0.211(\text { His })-0.944(\text { Tyr })
\end{aligned}
$$

The amino acid score (AAS) was calculated by the method of FAO/WHO as shown below:

$$
\begin{aligned}
& \text { AAS }= \\
& \frac{\text { mg of AA in } 1 \mathrm{~g} \text { of test protein }}{\text { mg of AA in } 1 \mathrm{~g} \text { of the FAO/WHO reference pattern }} \\
& \times 100
\end{aligned}
$$

The digestible indispensable amino acid (IAA) reference ratio was calculated to determine DIAAS of the samples, and each IAA reference ratio was calculated according to the following equation:

\section{Statistical analysis}

All experiments were replicated three times $(n=3)$ and each employed a new batch of ground chestnuts as an independent test. Analyses of data from all replications were performed by a one-way ANOVA test, followed by Duncan's new multiple range test with a 0.05 significance level using Statistical program 10.0 (Stat Soft Inc., Tulsa, OK, USA).

\section{Results and discussion}

\section{Proximate chemical analysis}

The proximate chemical compositions of the chestnut fruits from three different regions of China (HEN, HUN, and GD) were shown in Table 1. Chestnut from Hunan province had significantly higher moisture content than the samples from Henan and Guangdong province $(P<0.05)$. All chestnut fruits had

$$
\text { Digestible IAA reference ratio }=\frac{\mathrm{mg} \text { of digestible IAA in } 1 \mathrm{~g} \text { pretein of food }}{\mathrm{mg} \text { of the same dietary IAA in } 1 \mathrm{~g} \text { of the reference protein }}
$$

Digestible indispensable amino acid score (DIAAS) was calculated as shown below: ${ }^{23}$

DIAAS $(\%)=100 \times$ lowest value of digestible IAA reference ratio

\section{Electrophoresis}

Total protein isolate and protein fractions of three different Chinese chestnuts (HEN, HUN, and GD) were all used for sodium dodecyl sulphate polyacrylamide gel electrophoresis (SDS-PAGE) studies. SDS-PAGE was performed with $12.5 \%(\mathrm{v} / \mathrm{v})$ bisacrylamide gel and $4 \%(\mathrm{v} / \mathrm{v})$ stacking gel in a DYCZ-24DN mini-Protein electrophoresis (Sixty-one Instrument, Beijing, China). The electrophoresis buffer consisted of $125 \mathrm{mM}$ Tris, $5 \mathrm{M}$ urea at $\mathrm{pH} 6.8,0.2 \%(\mathrm{v} / \mathrm{v})$ SDS, 20\% (v/v) glycerol, and $0.01 \%(\mathrm{w} / \mathrm{v})$ bromophenol blue. Defatted chestnut sample (6 mg) was mixed with $420 \mu \mathrm{L}$ extraction buffer and incubated for $1 \mathrm{~h}$. The extraction buffer was composed of $50 \mathrm{mM}$ Tris, $5 \mathrm{M}$ urea at $\mathrm{pH} 8.0,0.2 \%(\mathrm{v} / \mathrm{v}) \mathrm{SDS}, 2 \%(\mathrm{w} / \mathrm{v})$ reducing agent (2mercaptoethanol). The samples were then mixed with $420 \mu \mathrm{L}$ electrophoresis buffer. This solution was heated at $95{ }^{\circ} \mathrm{C}$ for $5 \mathrm{~min}$ with constant shaking. Aliquots of $6 \mu \mathrm{L}$ of prepared sample were loaded into each well. The electrophoretic separation was conducted at $200 \mathrm{~V}$ for $50 \mathrm{~min}$. The gels were stained with Coomassie blue solution for $30 \mathrm{~min}$ with constant shaking, and then destained twice with $45 \%(\mathrm{v} / \mathrm{v})$ ultrapure water, $45 \%(\mathrm{v} / \mathrm{v})$ methanol and $10 \%(\mathrm{v} / \mathrm{v})$ acetic acid solution respectively for $1 \mathrm{~h}$, and once with $5 \%(\mathrm{v} / \mathrm{v})$ acetic acid and $22.5 \%(\mathrm{v} / \mathrm{v})$ methanol solution for $12 \mathrm{~h}$. The gels were scanned by a Sharp JX-330 scanner (Amersham Biosciences, Quebec), and the integrated intensities of electrophoresis protein bands were analyzed with Image Master ID Elite software (Version 2.0, Amersham Biosciences). The protein composition was calculated as the total areas under all the peaks. $^{24}$ a moisture content greater than $46 \%$, while the mean moisture content was $47.58 \%$, which was lower than that of Spanish chestnuts $(54.00 \%) .{ }^{25}$ The American chestnut variety had a similar moisture content. ${ }^{26}$ The average ash contents of these Chinese chestnut fruits $(1.59 \%)$ were similar to or less than the Turkish chestnuts $(1.00-3.20 \%){ }^{27}$

The crude protein contents were $8.12 \%$ (HEN), 9.74\% (HUN) and $7.54 \%$ (GD) respectively, which were similar with that reported by Pereira-Lorenzo $(4.50-9.60 \%) .{ }^{25}$ Soluble protein content calculated by the protein fractions ranged from $4.86 \%$ (GD) to $6.68 \%$ (HUN), which were also consistent with the report of Pereira-Lorenzo. ${ }^{25}$ Soluble protein content was lower than the total protein contents in Table 1 because of the presence of insoluble protein. The average soluble protein content of Chinese chestnut fruits was $5.70 \%$ and there was not a definitive geographic pattern. That is to say, the regional variation was found to be relatively small.

\section{Protein fractionation}

Osborne solubility-based protein fractionation data (Table 2) indicated that albumin (71.62\% of the total soluble protein)

Table 1 Proximate chemical analysis $(\mathrm{g} / 100 \mathrm{~g})^{b}$ of chestnut fruits from three different regions of China (HEN, HUN, and GD)

\begin{tabular}{lllll}
\hline Region & Moisture & Ash & Crude protein & Soluble protein \\
\hline HEN & $46.43 \pm 0.31^{a}$ & $1.81 \pm 0.09^{a}$ & $8.12 \pm 0.13^{a}$ & $5.57 \pm 1.83^{a}$ \\
HUN & $49.75 \pm 0.26^{a}$ & $1.44 \pm 0.08^{a}$ & $9.74 \pm 0.24^{a}$ & $6.68 \pm 0.04^{a}$ \\
GD & $46.55 \pm 1.01^{a}$ & $1.51 \pm 0.04^{a}$ & $7.54 \pm 0.22^{a}$ & $4.86 \pm 0.05^{a}$ \\
Ave & $47.58 \pm 1.88$ & $1.59 \pm 0.20$ & $8.47 \pm 1.14$ & $5.70 \pm 0.92$
\end{tabular}

${ }^{a}$ Means $(n=3) \pm$ standard deviations within a column with different superscripts differ significantly $(P<0.05)$. ${ }^{b}$ For moisture, the unit is on a wet weight basis; for all other components, the unit is on a dry weight basis. 
Table 2 Protein fractionation yields ${ }^{b}$ of chestnut fruits from three different regions of China (HEN, HUN, and GD)

Osborne protein

fraction Albumin Globulin Prolamin Gluten

\begin{tabular}{lllll}
\hline HEN & $67.50 \pm 0.02^{a}$ & 0 & 0 & $32.50 \pm 0.02^{a}$ \\
HUN & $78.44 \pm 0.02^{a}$ & 0 & 0 & $21.56 \pm 0.01^{a}$ \\
GD & $68.93 \pm 0.02^{a}$ & 0 & 0 & $31.07 \pm 0.01^{a}$ \\
Ave & $71.62 \pm 5.95$ & 0 & 0 & $28.38 \pm 5.95$
\end{tabular}

${ }^{a}$ Means $(n=3) \pm$ standard deviations within a column with different superscripts differ significantly $(P<0.05) .{ }^{b}$ For protein fractionation yields, the data are percentage of total soluble protein.

were the most dominant, followed by glutens $(28.38 \%)$. The globulin and prolamin were nondetectable in all the Chinese chestnut fruits. The albumin content of HUN was highest (5.24\%), followed by HEN (3.76\%) and GD (3.35\%). The ratios of albumin to gluten of the three chestnut proteins (HEN, HUN, and GD) were 2.1, 3.7, and 2.3, respectively. This obvious difference makes it possible to distinguish different sources of chestnut proteins. The absence of globulins in the Chinese

Table 3 Amino acid composition, E/T (100\%), EAAI, and predicted protein efficiency ratio (PER) of chestnut fruits from three different regions of China (HEN, HUN, and GD) (g/100 g of protein isolate)

\begin{tabular}{|c|c|c|c|c|}
\hline Amino acid & HEN & HUN & GD & $\begin{array}{l}\text { FAO/WHO (2013) standarc } \\
\text { mode for older children, } \\
\text { adolescents and adults }\end{array}$ \\
\hline Ile & 3.9 & 3.8 & 4.2 & 3.0 \\
\hline Leu & 6.8 & 6.7 & 7.4 & 6.1 \\
\hline Lys & 6.3 & 6.3 & 6.4 & 4.8 \\
\hline Met & 1.8 & 1.6 & 1.9 & \\
\hline Cys & 2.1 & 2.2 & 1.9 & \\
\hline $\begin{array}{l}\text { Total sulphur } \\
\text { amino acids }\end{array}$ & 3.9 & 3.8 & 3.8 & 2.3 \\
\hline Tyr & 2.6 & 2.8 & 3.4 & \\
\hline Phe & 3.9 & 4.0 & 5.0 & \\
\hline $\begin{array}{l}\text { Total aromatic } \\
\text { amino acids }\end{array}$ & 6.5 & 6.8 & 8.4 & 4.1 \\
\hline Thr & 4.1 & 4.0 & 4.4 & 2.5 \\
\hline Val & 5.8 & 4.7 & 4.9 & 4.0 \\
\hline His & 2.9 & 2.8 & 2.7 & 1.6 \\
\hline Trp & 1.2 & 1.3 & 1.0 & 0.66 \\
\hline $\begin{array}{l}\text { Total essential } \\
\text { amino acids }\end{array}$ & 38.5 & 37.4 & 40.5 & 27.5 \\
\hline Asp & 18.3 & 19.1 & 16.6 & \\
\hline Glu & 16.0 & 15.8 & 16.5 & \\
\hline Ser & 4.3 & 4.1 & 4.6 & \\
\hline Gly & 4.7 & 4.6 & 4.9 & \\
\hline $\operatorname{Arg}$ & 7.5 & 9.3 & 6.8 & \\
\hline Ala & 5.6 & 6.0 & 6.1 & \\
\hline Pro & 5.2 & 3.7 & 3.9 & \\
\hline $\begin{array}{l}\text { Total non-essential } \\
\text { amino acids }\end{array}$ & 62.3 & 62.6 & 59.4 & \\
\hline$E / T(\%)$ & 38.5 & 37.4 & 40.5 & \\
\hline EAAI & 77.7 & 76.0 & 79.0 & \\
\hline PER-1 & 2.2 & 2.2 & 2.5 & \\
\hline PER-2 & 2.4 & 2.3 & 2.5 & \\
\hline PER-3 & 2.7 & 2.3 & 2.2 & \\
\hline
\end{tabular}

chestnut protein is quite different from those from beans $(63.93 \%)^{27}$ and cowpea seeds $(66.6 \%),{ }^{28}$ and it maybe the distinctive features of Chinese chestnut protein.

\section{Amino acid composition and nutritional value evaluation}

The amino acid composition of chestnut fruits from three different regions of China (HEN, HUN, and GD) were shown in Table 3, while their AAS and DIAAS were shown in Table 4. All the Chinese chestnut fruit proteins were found to be rich in aspartic acid (16.6-20.1 g/100 g protein) and glutamic acid (15.8-17.0 g/100 g protein), which agreed well with previous reports. ${ }^{29}$ According to Phat et al. ${ }^{30}$ the high levels of aspartic and glutamic acids were responsible for the special favour and taste. The sulphur-containing amino acid content (methionine and cystine) was 3.9, 3.8 and $3.8 \mathrm{~g} / 100 \mathrm{~g}$ protein for HEN, HUN and GD, respectively, which indicated that the Chinese chestnut fruits had higher content of the sulphur-containing amino acids than that of FAO/WHO (2013) standard mode for older children,

Table 4 Score of chestnut fruits from three different regions of China (HEN, HUN, and GD). (a) AAS of chestnut fruits from three different regions of China (HEN, HUN, and GD). (b) DIAAS of chestnut fruits from three different regions of China (HEN, HUN, and GD) ${ }^{c}$

(a)

\begin{tabular}{llll}
\hline Amino acids score & HEN & HUN & GD \\
\hline Ile & $130.00^{b}$ & 126.67 & 140.00 \\
Leu & $111.48^{a}$ & $109.84^{a}$ & $121.31^{a}$ \\
Lys & 131.25 & 131.25 & 133.33 \\
Met + Cys & 169.57 & 165.22 & 165.22 \\
Phe + Tyr & 158.54 & 165.85 & 204.88 \\
Thr & 164.00 & 160.00 & 176.00 \\
Val & 145.00 & $117.50^{b}$ & $122.50^{b}$ \\
Trp & 181.82 & 196.97 & 151.52 \\
His & 181.25 & 175.00 & 168.75 \\
Total essential amino acids & 140.00 & 136.00 & 147.27 \\
\hline
\end{tabular}

(b)

\begin{tabular}{llll}
$\begin{array}{l}\text { Digestible IAA reference } \\
\text { ratio }^{d}\end{array}$ & HEN & HUN & GD \\
\hline Ile & 1.09 & 1.06 & 1.17 \\
Leu & 0.93 & 0.91 & 1.01 \\
Lys & 1.05 & 1.05 & 1.07 \\
Met + Cys & 1.45 & 1.41 & 1.71 \\
Phe + Tyr & 1.32 & 1.38 & 1.71 \\
Thr & 1.26 & 1.23 & 1.35 \\
Val & 1.16 & 0.94 & 0.98 \\
Trp & 1.64 & 1.77 & 1.36 \\
His & 1.27 & 1.23 & 1.18 \\
DIAAS $(\%)^{e}$ & $93($ Leu $)$ & $91($ Leu) & 98 (Val)
\end{tabular}

${ }^{a}$ Means the first limited amino acid. ${ }^{b}$ Means the second limited amino acid. ${ }^{c}$ Indispensable amino acid (IAA) digestibility coefficients are based on predicted human values obtained from pig data. ${ }^{32}$ ${ }^{d}$ Digestible IAA reference ratio (digestible IAA in $1 \mathrm{~g}$ protein of chestnut fruit/mg of the same dietary indispensable amino acid in $1 \mathrm{~g}$ of the reference protein). ${ }^{e}$ DIAAS for chestnut fruit (lowest value of the 'digestible IAA reference ratio' expressed as \% for each reference pattern). 
adolescents and adults $(2.3 \mathrm{~g} / 100 \mathrm{~g})$. Total aromatic amino acid content of the three chestnut proteins was higher than the requirement of $\mathrm{FAO} / \mathrm{WHO}$ (2013) for older children, adolescents and adults, while total essential amino acid content was higher than the requirement of FAO/WHO (2013) for older children, adolescents and adults and all $E / T$ values were about $37 \%$, which was considered adequate for an ideal protein (FAO/WHO, 2013). The greater the EAAI, the more balanced amino acid composition and the higher quality and efficiency of the protein. ${ }^{31}$ The EAAI of the three chestnut proteins were all higher than 100, which suggested that the amino acid composition of Chinese chestnut is superior to FAO/WHO (2013) standard. The predicted PER-1 and PER-2 values (Table 3) of GD were higher than those of HEN and HUN, suggesting that GD might have higher digestibility.
Based on the analyse above, leucine was the first limiting amino acid for all the Chinese chestnut proteins (Table 4). The second limiting amino acid was isoleucine for HEN, whereas for HUN and GD, the second limiting amino acid was valine, respectively. However, total essential amino acid scores for the three Chinese chestnut proteins could reach the FAO/WHO requirement (2013) for older children, adolescents and adults. As a result, the essential amino acid composition of Chinese chestnut protein was reasonable, which was similar with that of Chinese kabuli and desi chickpea (Cicer arietinum L.) cultivars. ${ }^{9}$

DIAAS was calculated to evaluate the protein quality of Chinese chestnut fruits. It is a new and advanced recommended method of measuring protein quality (FAO, 2013) and is on the basis of the lowest amount of the digestible dietary indispensable amino acid per unit of the dietary protein. Table $4(\mathrm{~b})$

(a)

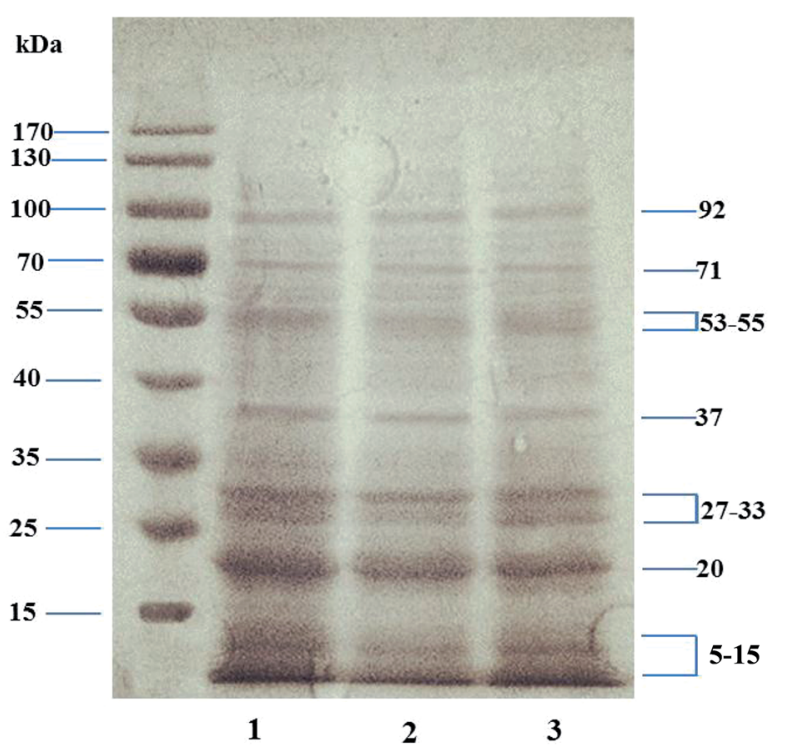

(b)
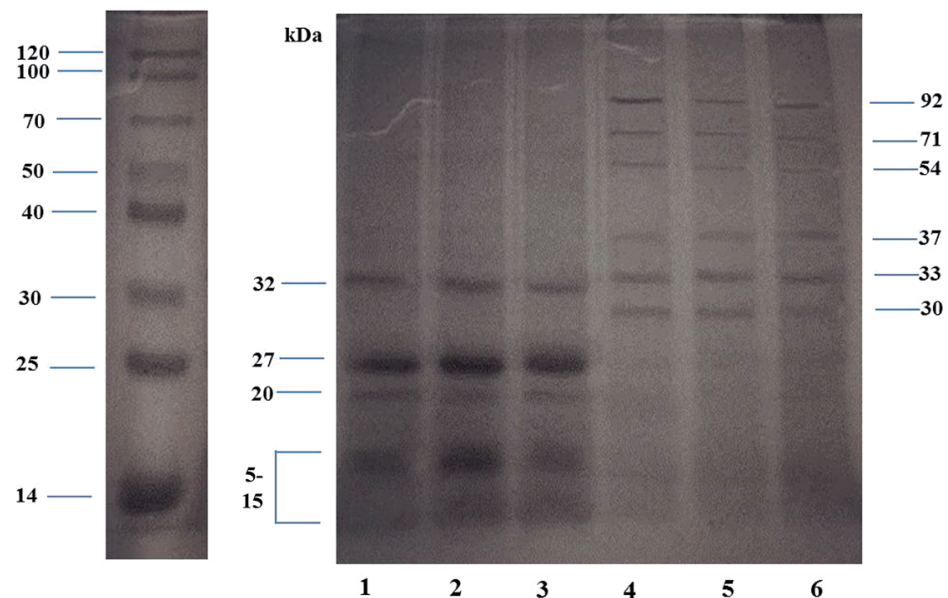

Fig. 1 (a) SDS-PAGE spectra of the chestnut fruits protein from three different regions of China*, and (b) SDS-PAGE spectra of chestnut fruits albumin and glutelin fractions**. *(1) HUN; (2) GD; (3) HEN. **(1) albumin of HUN; (2) albumin of HEN; (3) albumin of GD; (4) glutelin of HUN; (5) glutelin of HEN; (6) glutelin of GD. 
presents the DIAAS values for the proteins in the analyzed three chestnut fruits. True ileal digestibility coefficients for indispensable amino acids in these proteins were obtained from growing pigs, ${ }^{32,33}$ which have been recommended by the FAO if true ileal amino acid digestibility data derived from humans were absent. ${ }^{15}$ It is considered as 'Excellent', if DIAAS $\geq 100 \%$; 'Good', if DIAAS between 75\% and 99\%; and 'Low' if DIAAS < $75 \%$. When the FAO (2013) reference pattern for older children, adolescents and adults was employed, the scores ranged from 91\% (Leu) in HUN to 98\% (Val) in HUN. DIAAS values for the three chestnut fruits were close and were all higher than $90 \%$, which could be identified as 'good' quality. It should be noticed that most of the plant proteins are of 'low' quality (DIAAS < $75 \%) .{ }^{34,35}$ The DIAAS value of the Chinese chestnut fruits is higher than many other plant proteins, for example, rice (DIAAS $=73 \%$ ), wheat flour (DIAAS $=51 \%$ ), and lentils (DIAAS $=54 \%$ ). This indicates that the protein of chestnut fruit is a good kind of plant protein and it contains a surplus amount of indispensable amino acids (total essential amino acids $>37 \%$ ), which can greatly improve the developing countries' typical low-quality diets.

\section{Electrophoresis (SDS-PAGE)}

SDS-PAGE spectra of Chinese chestnut proteins were shown in Fig. 1, which indicated that the molecular weight distributions of all the Chinese chestnut proteins were similar. Fig. 1(a) showed that the three Chinese chestnut proteins were mainly comprised of seven polypeptide segments having the molecular weights of (91-93) kDa, (70-72) kDa, (53-55) kDa, $37 \mathrm{kDa},(27-$ 33) $\mathrm{kDa}, 20 \mathrm{kDa}$, and (5-15) kDa. Fig. 1(b) showed that the albumins from all the Chinese chestnut proteins were mainly comprised of four polypeptide segments with the molecular weights of Alb-1 (32 kDa), Alb-2 (27 kDa), Alb-3 (20 kDa) and Alb$4(5-15 \mathrm{kDa})$. The glutelin from the three chestnut proteins were mainly comprised of six polypeptide segments, which had the molecular weights of Glu-1 (92 kDa), Glu-2 (71 kDa), Glu-3 (54 kDa), Glu-4 (37 kDa), Glu-5 (33 kDa) and Glu-6 (30 kDa).

The relative protein quantity in Table 5 showed that the major proteins present in the Chinese chestnut were in the range of 5-20 kDa (the bands 6 and 7) and 27-53 kDa (the bands 3,4 , and 5). The result was similar as that of Sánchez-Vioque

Table 5 Molecular weight and relative protein quantity of different protein fragments of the chestnuts from three different regions of China (HEN, HUN, and GD)

Relative protein quantity

(\%)

\begin{tabular}{llrrr} 
Band number & $\begin{array}{l}\text { Molecular weight } \\
(\mathrm{kDa})\end{array}$ & HEN & HUN & GD \\
\hline 1 & $91-93$ & 3.5 & 4.9 & 4.1 \\
2 & $70-72$ & 4.4 & 6.8 & 6.1 \\
3 & $53-55$ & 10.0 & 12.0 & 11.2 \\
4 & 37 & 3.8 & 4.1 & 4.0 \\
5 & $27-33$ & 26.7 & 25.7 & 25.4 \\
6 & 20 & 24.4 & 21.9 & 25.3 \\
7 & $5-15$ & 27.2 & 24.6 & 24.0
\end{tabular}

et al. ${ }^{36}$ who reported that the major components of chickpea protein were in the range of $40-47 \mathrm{kDa}$ and $24-25 \mathrm{kDa}$. Total relative protein quantity of the bands 5,6 , and 7 , which contained the albumins fraction of Chinese chestnut proteins was $78.3 \%$ for HEN, $72.2 \%$ for HUN and $74.7 \%$ for GD, whereas total relative protein quantity of the bands $1,2,3$ and 4 was $21.7 \%$ for HEN, $27.8 \%$ for HUN and $25.3 \%$ for GD. Interestingly, the albumins of the three Chinese chestnut proteins were very high (more than 70\%) and they were made up of subunits with low molecular weight (5-32 kDa). It was thought that the lower molecular weight may be helpful to improve water solubility and digestibility of the chestnut protein.

\section{Conclusions}

To sum up, amino acid components of chestnut fruits from three different regions of China (HEN, HUN and GD) were analyzed in this paper to evaluate the nutritional value of Chinese chestnuts. Albumin and gluten were the two major protein components of Chinese chestnut, while globulin and prolamin were absent. Leucine was found to be the limiting amino acids for all the Chinese chestnut proteins, so chestnut should be combined with leucine-rich food in future food research and development to get better digestibility. According to DIAAS based on the FAO/WHO (2013) requirement of the essential amino acids for older children, adolescents and adults, Chinese chestnut (DIAAS $>90 \%$ ) was a good source of plant protein with a better digestibility than other plant proteins. SDS-PAGE indicated that the three Chinese chestnut proteins were rich in albumins with low molecular weight subunits (5-32 kDa) and they showed almost the same band components. Therefore, Chinese chestnut protein can be utilized as a good source of plant protein for human nutrition.

\section{Conflicts of interest}

There are no conflicts to declare.

\section{Acknowledgements}

This study was supported by the National Natural Science Foundation of China (Grant No. 31701604) and Scientific Research Foundation of Wuhan Institute of Technology (Grant No. k201633). Fang Yang expresses her gratitude for the postdoctoral opportunity at the University of Kentucky where a portion of the study was conducted.

\section{References}

1 F. Yang, Q. Liu, S. Y. Pan, C. Xu and Y. L. L. Xiong, Food Biosci., 2015, 11, 33.

2 T. Delgado, J. A. Pereira, E. Ramalhosa and S. Casal, Eur. Food Res. Technol., 2016, 242, 1299.

3 M. De Vasconcelos, R. N. Bennett, E. A. S. Rosa and J. V. Ferreira-Cardoso, J. Sci. Food Agric., 2010, 90, 1578.

4 M. Riche and T. N. Williams, Aquacult. Nutr., 2010, 16, 223. 
5 Y. J. Zheng, Y. Li, Y. L. Zhang, R. G. Zhang, Q. A. Zhang, Y. F. Zhang and S. L. Zhao, RSC Adv., 2015, 5, 12613.

6 Q. Li, X. H. Shi, Q. J. Zhao, Y. H. Cui, J. Ouyang and F. Xu, Food Chem., 2016, 201, 80.

7 B. Goncalves, O. Borges, E. Rosa, J. Coutinho and A. P. Silva, Fruits, 2012, 67, 201.

8 W. M. Miner-Williams, B. R. Stevens and P. J. Moughan, Nutr. Res. Rev., 2014, 27, 308.

9 X. S. Wang, W. R. Gao, J. S. Zhang, H. Zhang, J. G. Li, X. L. He and H. Ma, Food Res. Int., 2010, 43, 567.

10 P. Da Silva, I. Rahioui, C. Laugier, L. Jouvensal, H. Meudal, C. Chouabe, A. F. Delmas and F. Gressent, J. Biol. Chem., 2010, 285, 32689.

11 P. Tsaytler, H. P. Harding, D. Ron and A. Bertolotti, Science, 2011, 332, 91.

12 B. Coste, B. L. Xiao, J. S. Santos, R. Syeda, J. Grandl, K. S. Spencer, S. E. Kim, M. Schmidt, J. Mathur, A. E. Dubin, M. Montal and A. Patapoutian, Nature, 2012, 483, 176.

13 H. X. Wang and T. B. Ng, Protein Expression Purif., 2003, 32, 44.

14 C. Collada, L. Gomez, R. Casado and C. Aragoncillo, Plant Physiol., 1997, 115, 71.

15 R. R. Wolfe, S. M. Rutherfurd, I. Y. Kim and P. J. Moughan, Nutr. Rev., 2016, 74, 584.

16 B. Goncalves, O. Borges, H. S. Costa, R. Bennett, M. Santos and A. P. Silva, Food Chem., 2010, 122, 154.

17 O. Borges, B. Goncalves, J. L. S. de Carvalho, P. Correia and A. P. Silva, Food Chem., 2008, 106, 976.

18 U. D. Chavan, D. B. McKenzie and F. Shahidi, Food Chem., 2001, 75, 145.

19 A. M. Ghribi, I. M. Gafsi, C. Blecker, S. Danthine, H. Attia and S. Besbes, J. Food Eng., 2015, 165, 179.
20 Y. Okuno, Jpn. J. Parasitol., 1969, 18, 77.

21 J. Boye, R. Wijesinha-Bettoni and B. Burlingame, Br. J. Nutr., 2012, 108, S183.

22 U. D. Chavan, D. B. McKenzie and F. Shahidi, Food Chem., 2001, 74, 177.

23 N. Shaheen, S. Islam, S. Munmun, M. Mohiduzzaman and T. Longvah, Food Chem., 2016, 213, 83.

24 E. M. Bainy, S. M. Tosh, M. Corredig, L. Woodrow and V. Poysa, J. Am. Oil Chem. Soc., 2008, 85, 581.

25 S. Pereira-Lorenzo, A. M. Ramos-Cabrer, M. B. DiazHernandez, M. Ciordia-Ara and D. Rios-Mesa, Sci. Hortic., 2006, 107, 306.

26 M. A. McCarthy and F. I. Meredith, Econ. Bot., 1988, 42, 29.

27 F. Koyuncu, M. Cetinbas and A. N. Yldirim, J. Am. Pomol. Soc., 2008, 62, 98.

28 C. W. Chan and R. D. Phillips, J. Agric. Food Chem., 1994, 42, 1857.

29 M. De Vasconcelos, R. N. Bennett, E. A. S. Rosa and J. V. Ferreira-Cardoso, Int. J. Food Sci. Technol., 2009, 44, 2613.

30 C. Phat, B. Moon and C. Lee, Food Chem., 2016, $192,1068$.

31 V. Bartova, J. Barta, A. Brabcova, Z. Zdrahal and V. Horackova, J. Food Compos. Anal., 2015, 40, 78.

32 D. I. Adewole, A. Rogiewicz, B. Dyck, C. M. Nyachoti and B. A. Slominski, J. Anim. Sci., 2017, 95, 2670.

33 S. M. Rutherfurd, K. Bains and P. J. Moughan, Br. J. Nutr., 2012, 108, S59.

34 S. K. Cervantes-Pahm, Y. H. Liu and H. H. Stein, Br. J. Nutr., 2014, 111, 1663.

35 S. M. Rutherfurd, A. C. Fanning, B. J. Miller and P. J. Moughan, J. Nutr., 2015, 145, 372.

36 R. Sánchez-Vioque, A. Clemente, J. Vioque, J. Bautista and F. Millan, Food Chem., 1999, 64, 237. 